\title{
Características clínicas, histopatológicas e imuno-histoquímicas do mastocitoma cutâneo equino: relato de caso*
}

\section{Clinical, histopathological and immunohistochemical chacteristics of equine cutaneous mastocytoma: case report}

\author{
Rachel Rios de Lacerda, ${ }^{* *}$ José Carlos Guilardi Pacheco, ${ }^{* * *}$ Celina Seiko Takenaka, ${ }^{* * *}$ \\ Luciana Neves Torres, ${ }^{* * *}$ Murillo Martinez Matheus, ${ }^{* * *}$ Natalia Franco de Oliveira e Oliveira, ${ }^{* * *}$ \\ Domingos Cachineiro Rodrigues Dias, ${ }^{* *}$ Rodrigo Romero Corrêa***
}

\begin{abstract}
Resumo
Uma égua puro sangue árabe, com 3 anos de idade, pertencente ao rebanho experimental da FMVZ-USP apresentou lesões tumorais cutâneas nos membros pélvicos direito e esquerdo com aproximadamente um ano de evolução. Notou-se nova formação cutânea com crescimento rápido na região do pescoço, e desde então, as lesões dos membros ganharam características inflamatórias. Foi realizada punção aspirativa da lesão do pescoço para análise citológica, em que se identificou infiltrado eosinofílico. Optou-se pelo início de tratamento conservativo com três infiltrações intralesionais consecutivas com corticoesteroide. A partir da falta de sucesso das infiltrações foram realizadas as excisões cirúrgicas totais dos nódulos do pescoço, membro pélvico direito e esquerdo. Todos os materiais obtidos dos procedimentos cirúrgicos foram enviados para avaliação histopatológica e imuno-histoquímica, nas quais se confirmou o diagnóstico de mastocitoma cutâneo. O animal recebeu alta após a cicatrização das feridas cirúrgicas e remissão dos sinais, e não demonstrou recidivas ou outras complicações advindas das lesões tumorais. Algumas neoplasias cutâneas são bem descritas e de comum ocorrência na espécie equina, como o sarcoide, melanoma, papiloma e tumor de células escamosas. Já o mastocitoma cutâneo consiste em neoplasia cutânea rara nessa espécie. Segundo a literatura, não parece existir uma predileção racial para o aparecimento deste tumor, entretanto, alguns autores citam o acometimento maior nos animais Puro Sangue Árabe. Para o estabelecimento do diagnóstico definitivo é importante a associação dos exames físico, histopatológico e imuno-histoquímico e, apesar desta neoplasia ser de raro aparecimento nos equinos, deve ser sempre considerada como diagnóstico diferencial.
\end{abstract}

Palavras chave: cavalo, mastocitose, neoplasia, tumor cutâneo.

\begin{abstract}
A 3 year-old mare, Arab, that belongs to the experimental herd of FMVZ-USP presented cutaneous tumor lesions on right and left posterior limb with approximately one year of evolution. A new formation with rapid growth was observed on the neck region, and since then, the limbs lesion gained inflammatory characteristics. Aspirative punction was performed on the neck formation in order to submit the sample to cytological analyses, in which eosinophilic infiltrate was identified. At this point, a conservative approach was chosen with three consecutive corticoid infiltrations. With lack of success of infiltrative therapy, neck, right and left posterior limbs lesions were surgically removed. The material obtained from surgical procedures were sent to histophatological and immunohistrochemical evaluation, that confirmed cutaneous mastocytoma diagnosis. The mare was discharged after all surgical wound were healed and after full remission of clinical signs, and did not show relapses or any other complication from tumor lesions. Some cutaneous tumors are well described and commonly occur in horses, such as sarcoids, melanoma, papilloma and squamous cell carcinoma. Cutaneous mastocytoma is considered a rare cutaneous tumor in this species. According to literature, equine mastocytoma do not have breed predilection, however, some authors mention a greater involvement in Purebreed Arabian horses. In order to establish a definitive diagnosis, it is important to associate physical exams to histophatological an immunohistochemical evaluation and, even though rare in horses, this neoplasm must be considered as a differential diagnosis.
\end{abstract}

Keywords: horse, mastocytosis, neoplasm, skin tumors.

\footnotetext{
${ }^{*}$ Recebido em 3 de maio de 2019 e aceito em 17 de setembro de 2019.

${ }^{* *}$ Universidade Federal da Bahia

***Universidade de São Paulo

Autor para correspondência: rachellacerda@gmail.com
} 


\section{Introduction}

Veterinary dermatology is a specialty that has been improving and its importance has been recognized over the last years (Pessoa et al. 2014). In equine medicine, this specialty is well represented by the occurrence of some common skin tumors, such as sarcoids, melanoma, papilloma and squamous cell carcinoma. However, other tumor dermatoses can undertake this species. Cutaneous mastocytoma, also known as cutaneous mastocytosis, is a rare cutaneous neoplasm in horses, $2 \%$ to $7 \%$ of all cutaneous tumors in this species (Schaffer et al. 2013; Knowles et al. 2016). It is usually benign, and has its origin on mast cells (Scott and Miller, 2010). Commonly located on the skin, it also has been reported to undertake other parts of the body, including the superior respiratory tract (Mair and Krudewig, 2008) eyes (Flores, et al. 2017) and limbs (Leadbeater, et al. 2010; Uehlinger, et al. 2010; Johnston and Zedler, 2018). Moreover, it may be present in the lips, naris, jaw, periorbital region, neck and body.

Clinically, at the inspection, it may be presented as nonspecific, ulcerative nodular lesions, which leads to the need of complementary diagnostic techniques, such as histopathology and immunohistochemistry. According to Scott and Miller (2010), mast cells tumors in equines does not show predilection for breed and may affect animals of different ages, nevertheless, it is considered that a large proportion of cases occur in Arab individuals (McEntee, 1991). These tumors are usually firm, solitary and well delimited, and has a favorable prognostic with low rate of relapse in most cases.

This work aims to report a case of cutaneous mastocytoma in a mare, characterizing its clinical aspects, diagnostic confirmation and therapeutic approach.

\section{Case report}

A 3-year-old Arab mare that belongs to the University of São Paulo experimental herd, presented nodular lesions on the left posterior limb, at the metatarsophalangeal joint (fetlock), and on the lateral region of the tarsometatarsal joint (hock) of the right posterior limb. These lesions had firm consistence and approximately 1-year evolution. The horse was submitted to a full clinical evaluation, which included a general physical examination and routine hematologic and biochemical exams.

Subsequently, a new nodular lesion of approximately $4 \mathrm{~cm}$ in diameter appeared in the neck region, and was submitted to aspirative punction for cytological examination. In this procedure, a volume of $5 \mathrm{ml}$ of yellowish limpid liquid, without sediment, similar to synovial fluid, was collected. This sample was submitted to cytological analysis, in which was identified eosinophilic infiltrate. After 3 months, the node in the neck region became larger, firm and painful when manipulated, and it was observed the presence of edema at the node location. It was noted the formation of two more cutaneous nodes, one on the lateral region of the right distal tibia, and the other on the right nodular lesion side of the neck base. A new punction was performed revealing eosinophilic infiltrate. Few days after the punctions the fetlock lesion drained a large amount of purulent secretion (figure 1A).

In view of the described findings, a therapeutic approach was chosen with intralesional infiltration in the fetlock lesion with 10 $\mathrm{mg}$ of isoflupredone acetate, which resulted in a 30\% reduction. This procedure was repeated two other times with a week interval, without obtaining the same response. Three weeks after the last infiltration, radical excision of the lesions on the left posterior fetlock, the right hock and the neck were performed (figure 1B). In the postoperative period the wounds were left opened for second intention healing. They were washed daily with antisseptics and bandage were applied at the region of the fetlock and hock of the affected limbs, until full remission of the lesions. All the material obtained were taken to hitopathological and imunnohistochemistry analyses.

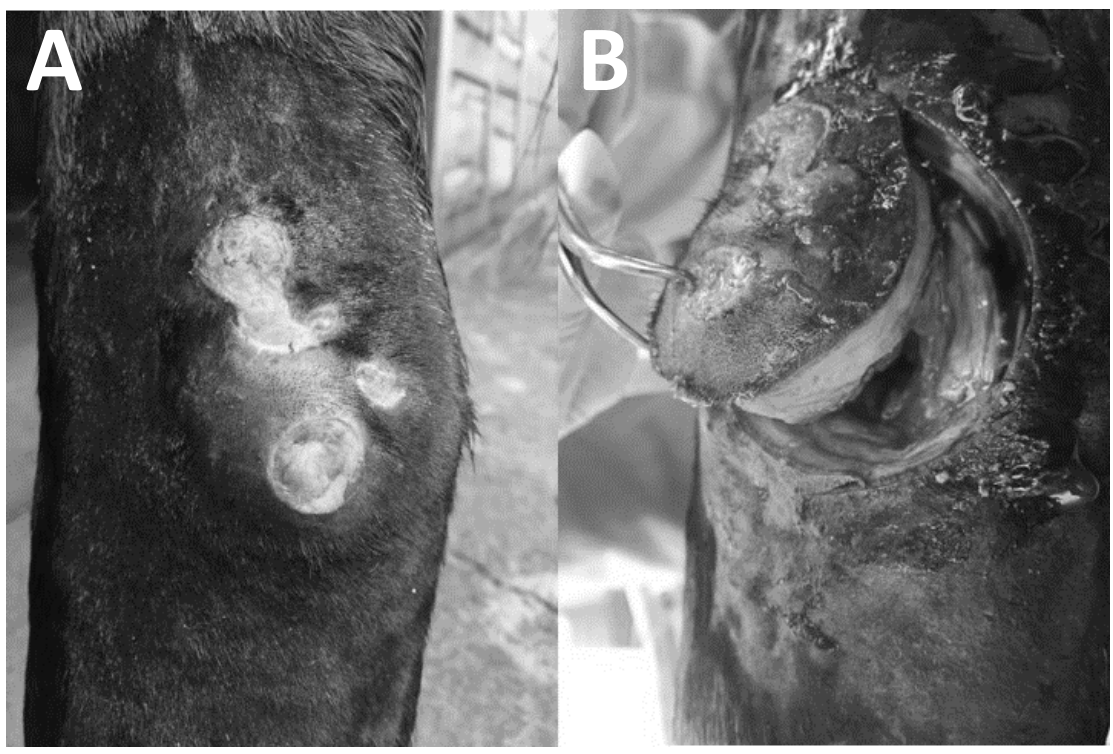

Figure 1: Lesion on fetlock region. A) Lesion on fetlock region, of the left posterior limb, after ulcerate and drain mucopurulent exudate. B) Radical exeresis of the affected tissue with ulcerated

Histopatologic exam was performed routinely. Firstly, the material was impregnated on paraffin with posterior hematoxilin and Eosin/Toluidin blue/PAS staining. On macroscopic evaluation of the neck fragment, measuring $4,0 \times 3,1 \times 1,7 \mathrm{~cm}$, it was observed on its central area a fissure with $0,5 \times 0,2 \mathrm{~cm}$, irregular edges and surface, brownish coloration and grayish center. When cut, it had firm consistence, darkish and whitish coloring, no delimitation and regular surface. Microscopically, it was observed dermal neoplastic proliferation, not demarcated, with no delimitation, composed by mast cells, posteriorly confirmed by toluidin blue staining, arranged as isolated aggregates and strings interspersed with marked eosinophilic infiltrate. These cells presented shapes that varied from polygonal to discrete fusiform, containing scarce cytoplasm with precise limits, rounded and sometimes elongated nuclei with moderate pleomorphism and evident anisocariasis and anisocytosis. The neoplasm was lined by epidermis with discrete regular hyperplasia associated with discrete compact orthokeratotic hyperkeratosis, with fistula associated with the fibrinoneutrophilic and hemorrhagic 
exudate, that extended to the dermis and the center of the lesion. It was also observed multifocal necrosis with eosinophils and degenerated neutrophils surrounded by fibrous tissue and histiocytic infiltrate (negative for detecting fungal agents on histochemical staing of PAS), in addition to discrete amount of hemosiderin-containing macrophages and poor margin distinction. These histopathological characteristics allowed diagnostic confirmation of equine cutaneous mastocytoma.

The samples obtained from the limb lesions, the biggest measuring 2,6 $\times 1,5 \times 1,6 \mathrm{~cm}$ and the smallest $1,6 \times 1,4 \times 1,4$ $\mathrm{cm}$, presented greyish coloration and irregular multilobulated surface. When cut, the consistence varied from soft to firm, had greyish and brownish coloration and an irregular multilobulated surface. Microscopically, there was non-delimited, nonencapsulated dermal neoplastic proliferation, composed of mast cells, confirmed in toluidine blue staining. These cells presented moderated cytoplasm, with round nucleus, with up to one conspicuous nucleolus and loose chromatin. It was noted a moderated pleomorphism, with moderated anisocytosis and discrete anisocariasis, presence of binucleate and multinucleate cells and rare mitoses. It was observed round cells focus arranged in nests, with round nucleus, broad and discreetly eosinophilic cytoplasm with distinct borders, sometimes with eosinophils. A discrete amount of hemosiderin-containing macrophages and multifocal areas of necrosis with eosinophils and degenerate neutrophils were observed, in addition to the absence of epidermis. Thus, morphological diagnostic of theses lesions was also determined as equine cutaneous mastocytoma.

The material obtained during the surgical procedures was taken for immunohistochemical evaluation which confirmed equine cutaneous mastocytoma diagnosis. The tissue sample obtained by excisional cutaneous biopsy of the nodule localized at the right hock, measured $6,0 \times 3,0 \times 2,0 \mathrm{~cm}$ was fixated on $10 \%$ formalin, histologically processed, and sections of $5 \mu \mathrm{m}$ were stained with hematoxylin-eosin (HE) and toluidine blue. For the immunohistochemical reaction, $5 \mu \mathrm{m}$ histological sections were submitted to the antigenic recovery procedure in citric acid solution $(10 \mathrm{mM}, \mathrm{pH}$ $6,0)$ in the pressure cooker for 20 minutes Afterwards, the slides were submitted to the endogenous peroxidase blockade in $6 \%$ aqueous solution of $\mathrm{H}_{2} \mathrm{O}_{2}$ for 30 minutes and subsequently, to inespecific binding blockade (Protein Block Spring, SPD 125) for $10 \mathrm{~min}$ at room temperature. Slides were incubated overnight with polyclonal primary antibody for KIT/CD117 (Dako, 1:1000), in a humid chamber, at $4^{\circ} \mathrm{C}$. Subsequently, the slides were incubated with a polymer system (Reveal HRP Spring, SPD 125 ) and revealed by the chromogen diaminobenzidine (DAB, Spring SPD 125). Finally, the slides were counterstained in Harris Hematoxylin in assemplies in Permont medium. The negative control was performed by replacing the primary antibody with its diluent (Spring, ADS 125). Histological evaluation was performed with standard KIT marking, according to the criteria proposed by Clarke et al. (2014) and Ressel, Ward and Kipar (2015).

Microscopic analysis revealed neoplastic mast cells proliferation on dermis, with infiltrative growth, non-encapsulated and accompanied by intense eosinophilic inflammatory infiltrate (Figure 2A-B). Neoplastic mast cells presented moderate pleomorphism, with rounded and central nuclei, loose chromatin, metachromatics cytoplasmic granules evidenced by toluidineblue stain (Figure 2C). Rare mitosis and bi/multinucleated cells were observed, besides multifocal necrosis areas. Immunohistochemistry test shown KIT marker positive reaction with diffuse distribution on neoplastic mast cells cytoplasm (Figure 2D). This result is associated to diffuse cytoplasmic reaction tumor relapse and increase of metastasis incidence (Clarke et al., 2014; Ressel et al. 2015). Although, in the present case, relapse and metastasis phenomena were not observed.

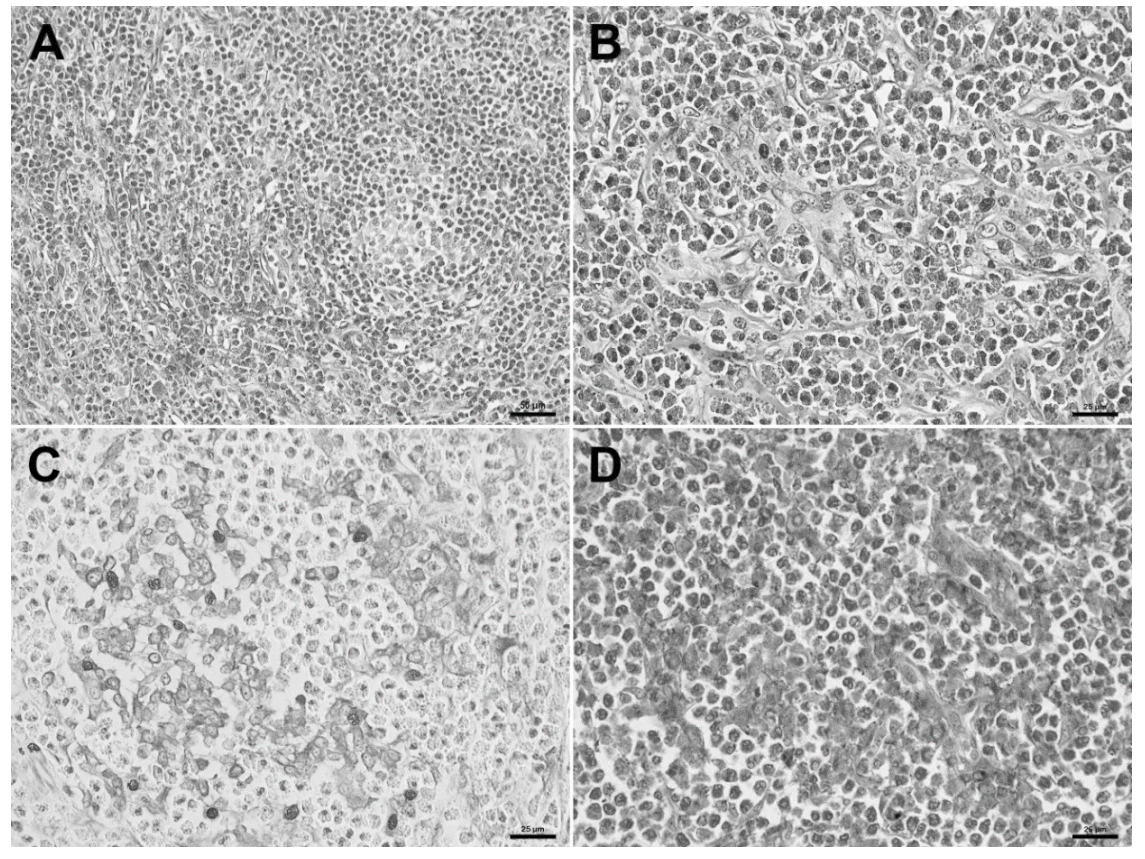

Figure 2: Microscopic analysis of the equine cutaneous mastocytoma. A) Dermal neoplastic mast cells proliferation interspersed with intense eosinophilic inflammatory infiltrate. HE, 20x B) Proliferations of neoplastic mast cells in the dermis. HE, 40x. C) Purple staining of metachromatic cytoplasmic granules of neoplastic mast cells. Toluidine blue, 40x D) Immunohistochemistry for KIT, showing diffuse marking pattern in the cytoplasm of neoplastic mast cells (KIT III standard). DAB, 40x.
Three months after full remission of the clinical signs, the animal was discharged from the clinic and, up to the present day, it is healthy, and does not show any signs of metastases, paraneoplastic syndromes, relapses or other complications.

\section{Discussion}

Despite recent advances, dermatology is a specialty that needs attention of equine practioners facing other areas of equine medicine, such as gastroenterology and orthopedics. Although many skin diseases are not fatal, this conditions may cause major financials losses by aesthetic depreciation of animals, treatment spend, development of complications and eventually occurrence of death of those patients (Pessoa et al., 2014). It is important to 
remember that among production domestic animals, horses are the most affected by dermatological diseases (Lloyd et al., 2008). Although this importance, the majority of equine dermatological illness do not have its etiological diagnosis defined (Monteiro et al., 2008), thus, treatments consists on empirical, symptomatic and palliative mode.

Most of dermatological lesions are diagnostic and therapeutic challenges, once they clinically appear like cutaneous syndrome with nonspecific features that on physical examination reveal only several primary and/or secondary lesions such as alopecia, pruritus, seborrhea, nodules, papules, pustules, ulcers among others, compatible with various primary or secondary skin diseases (Johnson, 1998). For this reason, it is necessary a clinical approach including patient identification, precise historic and anamnesis, general physical examination, dermatological physical examination and complementary exams like hematologic and biochemical testing, in addition to more specific techniques like histopathology testing for differential diagnosis determination (Speirs, 1997).

Among the main dermatoses of horses, those that have a neoplastic character stand out, such as sarcoid, melanoma, papilloma and squamous cell carcinoma (Lloyd et al., 2008). However, other neoplastic dermatosis may also affect these animals.

Mast cells tumors, or cutaneous mastocytomas, are unusual in horses, in comparison with other species. Clinical presentation with more than one lesion, like here presented, it is even more unusual, once normally these tumors are isolated and unique most times (Johnson, 1998; Mair and Krudewig, 2008).

Lesions are more frequently located on skin, but can arise in others locations, including superior respiratory tract and eyes, representing about $3,4 \%$ and $6,9 \%$ of all skin tumors in this species (Scott and Miller, 2010).

There is a rare form of congenital mastocytoma in horses, whose features vary from multiple spread nodules on the thorax or limbs, to focal lesions presenting just after the foal is born, and have spontaneous resolution (McAuliffe, 2013). These authors consider two forms of cutaneous mastocytoma in adult horses, one nominated nodular cutaneous mastocytosis, benign, with variable distribution over the body and firm and floating aspect. Another form, rarer, is equine malignant mastocytosis that have few reports, presenting pruritus, pain and metastasis occurrence as main characteristics. In those cases, it is likely the development of complications and evolution to death. Mair and Krudewig (2008) consider Word Healthy Organization classification of mastocytomas related in humans in three categories: cutaneous mastocytoma, considered benign restricted to skin lesions, systemic mastocytoma with four subgroups characterized by lesions in other tissues than skin, and finally, extracutaneous mastocytoma, considered extremely rare. These authors reported a variable clinical presentation of cutaneous mastocytoma in horses, that may present as lonely benign tumors restricted to skin lesions, more common, or systemic or multicentrical mastocytoma, rarer, but that had been related by Tan, Crisman, Clark, Gagea and Zimmerman (2007) in a Paint Horse that presented severe respiratory illness caused by this aggressive mastocytoma type.

In the present case, an Arabian horse was affected, which is in agreement with McEntee (1991) findings. Even though mastocytoma in horses does not have breed predilection, about $33 \%$ of occurrences on the author's report appeared on this specific breed.

Clinical presentation characterized by nodular isolated lesions distributed in different body parts, with fistulation evolution and mucopurulent drainage, even though rare, is compatible with Scott and Miller (2010) description. The authors described as well-defined lesions on the head, thorax and limbs, that varies from 0,5 to $20 \mathrm{~cm}$ in diameter, presenting slow growth, not metastatic, superficial and limited to dermis or subcutaneous tissue, being firm or floating on palpation and most of times capsulated. It is well reported that mast cells tumors in horses, however, are often firm, not mobile, and found in proximity to joints. All this features supported dermatological neoplastic suspicion.

The clinical approach of this kind of lesion demands the application of cytological and histopathologic testing for precise determination of diagnosis (Mair and Krudewig, 2008). Cytological and histopathologic features described in the present report were compatible and allowed cutaneous mastocytoma diagnosis, on its more common nodular form (Lloyd et al., 2008; Mair and Krudewig, 2008; Scott and Miller, 2010; McAuliffe, 2013; Clarke et al., 2014). Eosinophilic infiltration observation is justified, once that morphological characteristics diversity at microscopic exam may be attributed to cutaneous mast cell proliferative cellular event sequence. This may indicate that cells release chemotactic factors to eosinophilic infiltrate, leading to collagen degeneration and cellular necrosis with subsequent granulomatosis inflammation and fibrosis (McEntee, 1991).

In addition to histopathologic diagnosis, immunohistochemical test was applied using the protocol for molecular marker KIT (Clarke et al., 2014; Ressel et al., 2015) for determination and evaluation of the prognostic possibilities and occurrence of complications. The result demonstrated grade III for this molecular marker, what is compatible with relapse and metastatic tendency neoplasm, still not observed until the present moment.

Therapeutic options for equine cutaneous mastocytoma may vary from medical conservative approach, using corticosteroids and cimetidine, up to nitrogen cryotherapy techniques and radical surgical removal (Mair and Krudewig, 2008). In the present report, intralesional corticosteroid infiltration with oneweek interval was the first option. As the response was not satisfactory, radical surgical removal of the mass was performed with wide security margin between neoplastic and healthy tissue (McAuliffe, 2013).

Healing and lesion remission occurred three months after surgical procedures with second intention wound healing. The patient was discharged returning to routine herd management, and did not show any signs of complications and recurrence up to this date.

\section{Conclusion}

Equine cutaneous mastocytoma, although considered uncommon, is an important neoplastic dermatologic disease and should be included as a possible differential diagnosis in cases of skin tumors in this species. For precise diagnosis, it is necessary complementary resources beyond physical exam, 
as cytology, histopathology and imunohistochemistry in view of nonspecific and variable clinical presentation.

Although the majority of cases have clinical favorable features, good prognosis and benign evolution, monitoring and clinical following of the patient is necessary, once literature reports

\section{References}

CLARKE, L.; SIMON, A.; EHRHART, E.J.; MULICK, J.; CHARLES, B.; POWERS, B.; DUNCAN, C. Histologic characteristics and KIT staining patterns of equine cutaneous mast cell tumors. Veterinary Pathology, v. 51, n. 3, p. 560-562, 2014.

FLORES, A. R.; AZINHAGA, A.; PAIS, E.; FARIA, F.; NUNES, F.; GARTNER, F.; AMORIM, I. Equine ocular mast cell tumor: histopathological and immunohistochemical description. Journal of Equine Science, v. 28, n. 4, p. 149-152, 2017.

JOHNSON, P.J. (1998). Dermatologic tumors (excluding sarcoids). Veterinary Clinics of North America: Equine Practice, v. 14, n. 3, p. 625-658, 1998.

JOHNSTON, G. C. A.; ZEDLER, S. T. Treatment of an invasive equine mast cell tumour in the extensor carpi radialis by extensive tenomyectomy and local corticosteroid injections. Equine Veterinary Education, 2018.

KNOWLES, E.J.; TREMAINE, W.H.; PEARSON, G.R.; MAIR, T.S.A database survey of equine tumours in the United Kingdom. Equine Veterinary Journal. v. 48, n. 3, p. 280-284, 2016.

LEADBEATER, J. C.; GUTIERREZ-NIBEYRO, S. D.; BROWN, J. A. Mastocytoma in the common carpal sheath of the digital flexor tendons of a horse. Australian VeterinaryJjournal, v. 88, n. 1-2, p. 20-24, 2010.

LLOYD, D.; Littlewood, J.; Craig, M.; Thomsett, L.R. Practical Equine Dermatology. Hoboken, New Jersey: Blackwell Science Ltda, 2003, 135 p.

MAIR, T.S.; KRUDEWIG, C. Mast cell tumours (mastocytosis) in the horse: A review of the literature and report of 11 cases. Equine Veterinary Education, v. 20, n. 4, p. 177-182, 2008.

MCAULIFFE, S.B. Knottenbelt and Pascoe's Color Atlas of Diseases and Disorders of the Horse. $2^{\text {nd }}$ Ed., Philadelphia, Pa: Elsevier Itda. 2014, 544 p. recurrence of aggressive and fatal forms of this dermatologic disease.

In the present report, association between conservative therapy of intralesional infiltration and surgical removal was efficient on treatment of nodular cutaneous equine mastocytoma.

MCENTEE, M.F. Equine cutaneous mastocytoma: morphology, biological behaviour and evolution of the lesion. Journal of Comparative Pathology, v. 104, n. 2, p. 171-178, 1991.

MONTEIRO, G.A.; SOUZA, M.V.; CONCEIÇÃO, L.G.; LACERDA BALBI, C.; BORBA, R.; MOREIRA, M.A.S.; MOREIRA, J.D.C.L. Diagnóstico das dermatoses alopécicas multifocais em eqüinos da zona da mata mineira do Brasil. Veterinária e Zootecnia, v. 15, n. 1, p. 139-149, 2008.

PESSOAA.F.A.; PESSOA C.R.M.; MIRANDA NETO E.G.; DANTAS A.F.M.; RIET-CORREA F. Doenças de pele em equídeos no semiárido brasileiro. Pesquisa Veterinária Brasileira, v. 34, n. 8, p. 743-748, 2014.

RESSEL, L.; WARD, S.; KIPAR, A. Equine Cutaneous Mast Cell Tumours Exhibit Variable Differentiation, Proliferation Activity and KIT Expression. Journal of Comparative Pathology, v. 153, n. 4, p. $236-243,2015$.

SCOTT, D.W.; MILLER, W.H. Equine Dermatology-E-Book. Philadelphia, Pa: Elsevier Health Sciences. 2010, 736 p.

SCHAFFER, P.A., WOBESER, B., MARTIN, L.E., DENNNIS, M.M. AND DUNCAN, C.G. Cutaneous neoplastic lesions of equids in central United States and Canada: 3,351 biopsy specimens from 3,272 equids (2000-2010). Journal of the American Veterinary Medical Association v. 242, n. 1, p. 99-104, 2013.

SPEIRS, V.C. Clinical Examination of Horses. Philadelphia, Pa: W.B. Saunders. 1997, 358 p.

TAN, R. H.H.; CRISMAN, M.V.; CLARK, S.P.; GAGEA, M.; ZIMMERMAN, K. Multicentric mastocytoma in a horse. Journal of Veterinary Internal Medicine, v. 21, n. 2, p. 340-343, 2007.

UEHLINGER, F.D.; BURTON, S.A.; RILEY, C.B.; WICHTEL, M.E G.; BOURQUE, A.C. Cutaneous and tendon sheath mastocytomas with eosinophilic joint and tendon sheath effusions in a horse. Journal of Veterinary Internal Medicine, v. 24, n. 5, p. 1233-1236, 2010. 